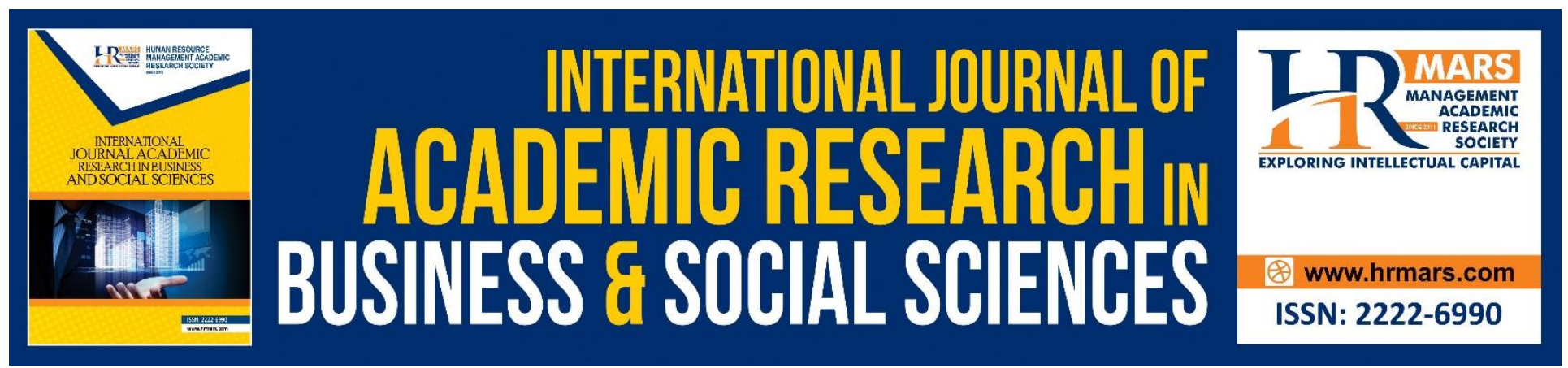

\title{
The Effect of Government Support Programs and Compliance Costs on Goods and Services Tax Compliance among Malaysian Batik Manufacturers
}

Norfadzilah Rashid, Nor Fara Shahirah Kamal, Nadiah Abd Hamid, Noorlaila Ghazali, Rohayu Yusop, Ahmad Syukri Zaid, Wan Norhayate Wan Daud, Asyraf Afthanorhan

To Link this Article: http://dx.doi.org/10.6007/IJARBSS/v8-i12/5065 DOI: $10.6007 /$ IJARBSS/v8-i12/5065

Received: 02 Nov 2018, Revised: 23 Dec 2018, Accepted: 28 Dec 2018

Published Online: 28 Dec 2018

In-Text Citation: (Rashid et al., 2018)

To Cite this Article: Rashid, N., Kamal, N. F. S., Hamid, N. A., Ghazali, N., Yusop, R., Zaid, A. S., ... Afthanorhan, A. (2018). The Effect of Government Support Programs and Compliance Costs on Goods and Services Tax Compliance among Malaysian Batik Manufacturers. International Journal of Academic Research in Business and Social Sciences, 8(12), 682-695.

\section{Copyright: (C) 2018 The Author(s)}

Published by Human Resource Management Academic Research Society (www.hrmars.com)

This article is published under the Creative Commons Attribution (CC BY 4.0) license. Anyone may reproduce, distribute, translate and create derivative works of this article (for both commercial and non-commercial purposes), subject to full attribution to the original publication and authors. The full terms of this license may be seen at: http://creativecommons.org/licences/by/4.0/legalcode

Vol. 8, No. 12, 2018, Pg. 682 - 695

Full Terms \& Conditions of access and use can be found at http://hrmars.com/index.php/pages/detail/publication-ethics 


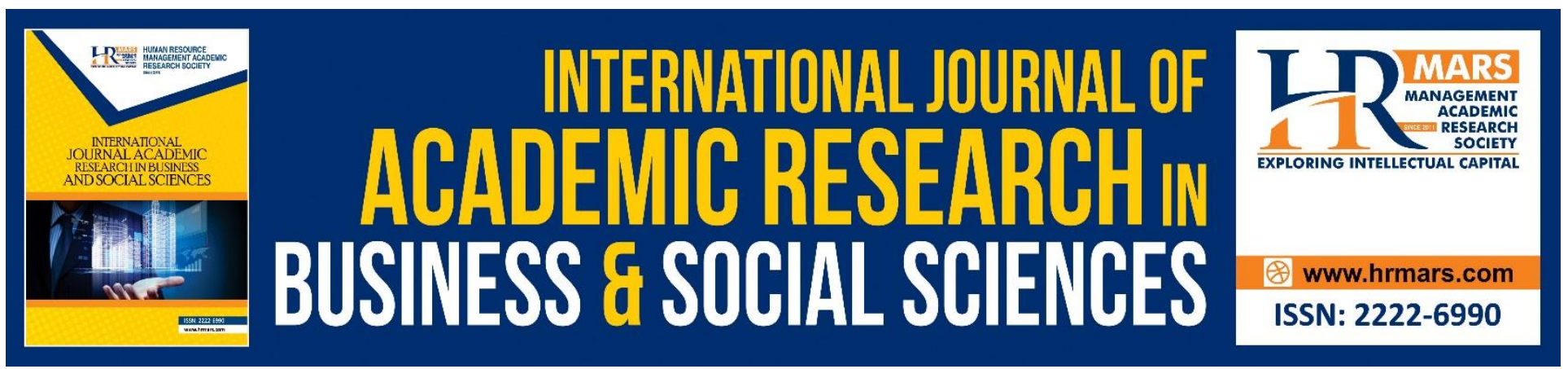

\title{
The Effect of Government Support Programs and Compliance Costs on Goods and Services Tax Compliance among Malaysian Batik Manufacturers
}

\author{
${ }^{1}$ Norfadzilah Rashid, ${ }^{2}$ Nor Fara Shahirah Kamal, ${ }^{3}$ Nadiah Abd \\ Hamid, ${ }^{4}$ Noorlaila Ghazali, ${ }^{5}$ Rohayu Yusop, ${ }^{6}$ Ahmad Syukri Zaid, \\ ${ }^{7}$ Wan Norhayate Wan Daud, ${ }^{8}$ Asyraf Afthanorhan \\ 2,3,4,5Faculty of Accountancy, Universiti Teknologi MARA Puncak Alam Campus, \\ Bandar Puncak Alam, Selangor, Malaysia \\ $1,6,7,8$ Faculty of Economics and Management Sciences, Universiti Sultan Zainal Abidin, 21300 Kuala \\ Nerus, Terengganu, Malaysia \\ Corresponding Author: nadiah201@salam.uitm.edu.my
}

\begin{abstract}
The Goods and Services Tax (GST) implementation in Malaysia has received mixed reactions from various parties such as businesses, policy makers, professionals, business associations and individuals. Despite the rejections from these parties, the government proceeded with implementing GST. On consequence, this has led to GST compliance issues. One of the issues that have been highlighted is high compliance cost. To address this issue, various Government Support Programs (GSPs) have been implemented in Malaysia particularly financial and credit assistance. Therefore, this study aims to determine the effect of GSPs on GST compliance among batik manufacturers in Malaysia. In addition, this study also examines the relationship between compliance cost in terms of fiscal cost, time cost and psychological costs on GST compliance among Malaysian batik manufacturers. Data was collected through a structured survey among Malaysian batik manufacturers. Based on the finding, the result showed that GSPs, time cost and psychological cost do affect GST compliance while fiscal cost did not affect GST compliance among batik manufacturer. The findings in this study provide awareness to the government on the need of more GSPs and other incentives to the batik manufacturers in order to encourage them to comply with GST.
\end{abstract}

Keywords: Goods and Services Tax (GST), Government Support Program (GSPS), GST compliance, Compliance Costs, Small and Medium Enterprises (SMEs), Malaysian Batik Manufacturers. 
INTERNATIONAL JOURNAL OF ACADEMIC RESEARCH IN BUSINESS AND SOCIAL SCIENCES

Vol. 8, No. 12, Dec, 2018, E-ISSN: 2222-6990 @ 2018 HRMARS

\section{INTRODUCTION}

The Goods and Services Tax (GST) implementation in Malaysia has raised many arguments from various parties including Small and Medium Enterprises (SMEs). SMEs contribute a significant amount of revenue to Malaysia as they are the largest business population representing $97.3 \%$ out of 645,136 businesses. It contributes $36.6 \%$ of GDP, $65.5 \%$ of employment and $17.6 \%$ on trade export. (SMIDEC Annual Report 2016). Due to the importance of this sector in the country's economy, it is vital to enhance GST compliance among SMEs taxpayer.

GST is a consumption tax imposed on the sale of goods and services. The primary aims of GST are to increase the efficiency of the tax collection system from previous Sales and Service Tax (SST) as well as become a major source of indirect income to the government in order to finance the socioeconomic development in Malaysia. However the implementation of GST would create extra burden particularly to SMEs and would encourage non-compliance issues. According to Chebusit et al., (2014), GST non-compliance issues can give negative impact on the economy where it can decrease tax revenue of the country. From previous studies, taxpayers non-compliance behaviour are due to several factors such as high compliance cost, inadequate knowledge on technical aspects of income tax system and taxpayers' attitudes and perceptions (Palil et al., 2013; Saad, 2013).

According to Eragbhe \& Omoye (2014), GST in some countries has significantly increased the compliance cost among businesses. GST compliance cost is a cost that needs to be incurred for record keeping of GST such as software and maintenance, preparation and filling of GST return. Many studies found that GST compliance cost is a burden to small businesses and show significant effect on the SMEs performance (Rametse \& Pope,2002; Evans, Lignier, \& Tran-Nam, 2013). It is also reported that some businesses had been forced to shut down due to their inability to bear production cost and high compliance cost (Berita Harian, 2015).

In order to encourage GST compliance and help to manage high compliance cost faced by SMEs, various government support programs (GSPs) have been implemented in Malaysia. GSPs in Malaysia focuses on five main areas namely, financial and credit assistance, technical and training assistance, extension and advisory services, marketing and market research and infrastructure support. Based on the SMEs Corporation's report, more than 100 types of financing scheme have been offered by various ministries and agencies to the SMEs. In this circumstance the GSPs is important for SMEs growth and sustainability.

Therefore, this study aims to examine the effect of GSPs and compliance cost on GST compliance among batik manufacturers. Batik manufacturing industry plays a big role in the country development and economic growth by providing job and business opportunities, especially in the rural areas (Teh, 1996). This study is expected to provide useful information for relevant authorities to improve on GSPs and GST implementation among SMEs in Malaysia. This study also is expected to make a contribution to the tax administration and policy developments literature for future references. 
INTERNATIONAL JOURNAL OF ACADEMIC RESEARCH IN BUSINESS AND SOCIAL SCIENCES

Vol. 8, No. 12, Dec, 2018, E-ISSN: 2222-6990 @ 2018 HRMARS

\section{LITERATURE REVIEW \& HYPOTHESIS DEVELOPMENT}

\section{GST Compliance}

The issues on tax compliance have been widely discussed among researchers. Ling et al. 2016 define GST compliance as the willingness of tax payer to follow the rules and regulation regarding on GST matter. While Nkwe (2013) claimed tax compliance is the degree in which a taxpayer obliges to tax rules and regulation. Previous studies shows that taxpayers attitude on compliance may be influenced by many factors. Kirchler (2007) revealed that taxpayers attitude on compliance may be influenced by taxpayers perception towards tax system, peer attitude, taxpayers understanding towards the tax system, motivations such as rewards, punishment such as penalties, cost of compliance, enforcement efforts, ethics of the taxpayer and tax collector, demographic factors such as the size of income and so on. Whereby, a study from Ling et al. (2016) found a positive relationship among the taxpayers' readiness to change towards GST compliance. Hanno and Violette (1996) suggested attitude has significant relationship towards tax compliance intention by employing theory of reasoned action (TRA). Moreover, Trivedi, Shehata, and Mestelman (2005) highlighted two important factors that may be related to tax compliance namely, the economic based theory that emphasize on incentive and the psychology-based theory that emphasize on attitude.

\section{Government Support Programs (GSPs)}

The Malaysia government introduced the GSPs for SMEs in the First Malaysian Plan (19661970). GSPs can be defined as a program, support and an incentive provided by the government to help the public in all areas such as education, business, healthcare and public welfare. It focuses on five main areas namely, financial and credit assistance, technical and training assistance, extension and advisory services, marketing and market research, and infrastructure support (Abdullah, 1999; Hilmi, Ramayah, Mustapha, \& Pawanchik, 2010; Ismail \& Othman, 2007). In line with the globalisation, numerous GSPs were introduced to SMEs to expand their business and be recognised internationally. In this circumstance, the GSPs is important for SMEs growth and sustainability. A study from Ismail and Othman (2007) found a significant relationship between GSPs and business growth. This indicates the importance of GSPs in strengthening the SMEs economy, improving the competition with the global market and enhancing social and economic environment. Thus, the first hypothesis of this study is developed:

Hypothesis 1 (H1): There is positive effect of the GSPs on GST compliance among batik manufacturers in Malaysia.

\section{GST Compliance Cost}

Previous studies have provided several definitions of compliance cost. One of the most used definitions of compliance cost is provided by Sandford (1989).

"Tax compliance costs are the costs incurred by taxpayers in meeting the requirements laid on them by the tax law and the revenue authorities. There are costs over and above the actual payment of tax and over and above any distortion costs inherent in the nature of the tax. These costs would disappear if the tax was abolished. They include the costs of collecting, remitting and accounting for 
INTERNATIONAL JOURNAL OF ACADEMIC RESEARCH IN BUSINESS AND SOCIAL SCIENCES Vol. 8, No. 12, Dec, 2018, E-ISSN: 2222-6990 @ 2018 HRMARS

tax on the products and profits of the business and on the wages and salaries of its employees, and also the costs of acquiring and updating the knowledge to enable this work to be done, including knowledge or legal obligations and penalties" (Sandford, 1989,p. 22).

GST compliance cost is a cost that needs to be incurred for record keeping of GST such as software and maintenance. Other compliance costs include preparation and filling of GST return, checking account, obtaining information on new procedures and policy of filling GST. GST compliance costs seem to be a burden to the SMEs as they have insufficient financial resources. This is consistent with previous studies that found GST compliance cost is a burden to small businesses (Rametse \& Pope, 2002).

Evans et al. ( 2013) used fiscal cost, time cost and psychological cost to determine the compliance cost of SMEs in Australia. Fiscal cost basically about the expenses that incur by business in order to fulfil the requirement and regulation of government taxation. Tran-Nam (2000) provided detailed examples of compliance cost comprising of cost to register the business for GST, cost on learning GST, new procedure and policy related to GST, and paying professional fees such as tax advisors and external auditors to get advice on GST. In addition they need to upgrade their tax and accounting software system or purchase new equipment such as cash register. Due to inadequate on technical knowledge of GST, businesses need to educate their staff by way of training. Therefore, second research hypothesis is developed:

Hypothesis 2 (H2): There is positive effect of the fiscal cost on GST compliance among batik manufacturers in Malaysia.

According to Sandford (1981) "time costs are incurred by the taxpayer, mainly on record keeping for tax purposes, completing the tax return and/or in preparing tax details for the tax professionals as well as time spent on dealing with the tax authorities".

In Malaysia, business need to record transactions occur by focusing on input and output tax, completing and submitting form GST 03 to Royal Malaysia Custom Department (RMCD) and also need to prepare the documents and tax details for Inland Revenue Board. The business has spent more time learning on GST thus affected their marketing and product strategy. The finding from the interview conducted by Glover \& Tran-Nam, (2005) found that small business accountant has to spend more time on tax matter and change their internal reporting from annually to quarterly basis. Thus, the third hypothesis of this study is developed:

Hypothesis $3(\mathrm{H} 3)$ : There is positive effect of the time cost on GST compliance among batik manufacturers in Malaysia.

On the other hand, psychological cost is more difficult to determine because it consists of the anxiety element in handling complex tax matters. Psychological cost is defined as "stress and anxiety experienced by business owners and individuals in having to satisfactorily deal with tax and other regulations" (Glover \& Tran-Nam, 2005, p. 240). Since the GST system is still new to the businesses, 
the businesses may face difficulties in adopting the system as they realise that they do not have sufficient knowledge.

Psychological cost increased more burden to SMEs as compared to larger corporation since they have limited resources to hire tax expertise (Evans et al., 2013). This is supported by Glover \& Tran-Nam (2005) study, which indicates that GST have increased the business owner stress level and worries as they need to deal with tax matters in order to avoid being penalised by tax authorities. Therefore, forth research hypothesis is developed:

Hypothesis $4(\mathrm{H} 4)$ : There is positive effect of the psychological cost GST compliance among batik manufacturers in Malaysia.

\section{METHODOLOGY}

\section{Population and Sample}

The population of this study consists of 823 batik manufacturers located at Kelantan and Terengganu who registered with Perbadanan Kemajuan Kraftangan Malaysia (PKKM). Terengganu and Kelantan are chosen because of the big population of batik manufacturers compared to the other states (Kraftangan Malaysia, 2017). The study used the probability sampling technique as this technique represents every member in the population to have an equal chance of being selected. A set of 250 questionnaires were randomly distributed by snail mail to the batik manufacturers. However, only 35 of the questionnaires were returned and useable. Later, the questionnaires were also distributed via online survey and e-mail. The questionnaires collected from online responses are 45 . As a result, the total questionnaires that valid and useable are 80 .

\section{Research Instrument}

For the data collection, a set of questionnaires was designed to gain primary data from the respondents about their experience on GSPs and how GST affects their business in terms of performance and compliance cost. The questionnaire was developed based on previous studies (Faridy et al., 2014; SME Corporation Malaysia, 2015; Yusoff et al., 2014) with some modifications to suit the context of this study.

There are 5 parts in the questionnaires. Part 1 consists of demographic information about gender, age, position, level of education, year of working experience and ethnicity. Part 2 is regarding company profile such as number of employees, length of business operation, location of the business and business performance. Part 3 comprises of 16 questions regarding GSPs experienced including general information about GSPs, type of GSPs received and challenges faced in obtaining GSPs. Part 4 consists of GST information such as the recording process of GST, visits from government official, benefits received from GST, cost incurred and opinion regarding GST implementation. Finally, Part 5 comprises of questions regarding GST implementation including compliance cost that covers fiscal cost, time cost and psychological cost.

The next section will discuss the results of this study by outlining the descriptive evidence of respondents as well determine the relationship between GSPs, compliance cost and GST compliance among batik manufacturers through t-test and multiple linear regression. 
INTERNATIONAL JOURNAL OF ACADEMIC RESEARCH IN BUSINESS AND SOCIAL SCIENCES

Vol. 8, No. 12, Dec, 2018, E-ISSN: 2222-6990 C 2018 HRMARS

\section{RESULTS}

Descriptive Statistics

Table 4.1 presents the descriptive statistics of the respondents' profile. As can be seen in Table 4.1 , the difference in number between the male and female respondents are high. They are only 24 male respondents from the 80 respondents. All the respondents in this study are Malay since they dominates the batik industry (Akhir \& Ismail, 2015). Most of the respondents are in the age bracket between 26 to 35 years old, followed closely by the respondents aged below 25 years old. As regards to their education, the descriptive statistics show that the education level of the respondents varies.

Table 4.1

\begin{tabular}{|c|c|c|}
\hline \multicolumn{3}{|c|}{ Respondents' Profile } \\
\hline Category & $\mathrm{N}$ & Percentage (\%) \\
\hline \multicolumn{3}{|l|}{ Gender } \\
\hline Male & 24 & 30.0 \\
\hline Female & 56 & 70.0 \\
\hline \multicolumn{3}{|l|}{ Age } \\
\hline$\overline{25}$ years or less & 23 & 28.7 \\
\hline $26-35$ years old & 24 & 30.0 \\
\hline $36-45$ years old & 17 & 21.3 \\
\hline $46-55$ years old & 10 & 12.5 \\
\hline 56 or above & 6 & 7.5 \\
\hline \multicolumn{3}{|c|}{ Highest Education Completed } \\
\hline PMR & 2 & 2.5 \\
\hline SPM & 19 & 23.75 \\
\hline STPM & 7 & 8.75 \\
\hline Vocational Education & 5 & 6.25 \\
\hline Diploma & 8 & 10.0 \\
\hline Degree & 33 & 41.25 \\
\hline Master Degree & 6 & 7.5 \\
\hline \multicolumn{3}{|l|}{ Job Position } \\
\hline Owner & 36 & 45.0 \\
\hline Manager & 12 & 15.0 \\
\hline Accountant & 12 & 15.0 \\
\hline Clerk & 15 & 18.75 \\
\hline Intern & 5 & 6.25 \\
\hline \multicolumn{3}{|l|}{ Working Experience } \\
\hline $1-5$ years & 45 & 56.3 \\
\hline $6-10$ years & 13 & 16.3 \\
\hline $11-15$ years & 3 & 3.8 \\
\hline $16-20$ years & 8 & 10.0 \\
\hline 20 years above & 11 & 13.8 \\
\hline Total & 80 & 100.0 \\
\hline
\end{tabular}

Table 4.2 explains on the business profile. First, majority of the batik manufacturers have less than 20 employees representing $86.25 \%$. This is consistent with the SME definitions in Malaysia. Most SMEs have been in operations for more than 10 years (67.5\%). In addition, this study shows that most batik manufacturers are located in Terengganu (60.0\%) and Kelantan (40.0\%). The result also shows 
INTERNATIONAL JOURNAL OF ACADEMIC RESEARCH IN BUSINESS AND SOCIAL SCIENCES

Vol. 8, No. 12, Dec, 2018, E-ISSN: 2222-6990 C 2018 HRMARS

that most of the batik manufacturers have revenue more than RM500,000 (52.5\%). In addition, out of the 80 respondents, $61.25 \%$ of the batik manufacturers have registered GST. Lastly, $50.3 \%$ of the batik manufacturers have become a beneficiary of the GSPs.

Table 4.2

Business Profile

\begin{tabular}{llc}
\hline Category & N & Percentage (\%) \\
\hline Number of employee & 43 & 53.75 \\
$1-5$ people & 26 & 32.5 \\
$6-20$ people & 10 & 12.5 \\
$21-35$ people & 1 & 1.25 \\
$35-50$ people & 29 & \\
\hline Length of year operation & 25 & 36.25 \\
$1-5$ years & 11 & 31.25 \\
$6-10$ years & 10 & 13.75 \\
$11-15$ years & 3 & 12.5 \\
$16-20$ years & 2 & 3.75 \\
$21-25$ years & & 2.5 \\
More than 26 years & 48 & \\
Location & 32 & 60.0 \\
Terengganu & & 40.0 \\
Kelantan & 38 & \\
Performance (Sales year 2015) & 42 & 47.5 \\
Below RM500, 000 & & 52.5 \\
Above RM500, 000 & 49 & \\
GST register & 31 & 61.25 \\
Yes & 45 & 38.75 \\
No & 35 & 56.25 \\
\hline Beneficiaries government support program & 80 & 43.75 \\
Yes & & \\
No & & \\
\hline Total & & \\
\hline
\end{tabular}

Reliability Test

The Cronbach's alpha test is to determine the reliability of the research instrument. The closer the Cronbach's alpha is to 1.00, the greater the internal consistency of items which indicates that the data is more reliable (George \& Mallery, 2003) and any alpha value that is greater than 0.60 , is considered as acceptable (Nunnally \& Bernstein, 1999). Table 4.3 shows that all the Cronbach's alpha values for this study are more than the acceptable level of 0.60 (George \& Mallery, 2003; Nunnally \& Bernstein, 1999). Even though the Cronbach's Alpha value for fiscal cost is lower as compared to the 
INTERNATIONAL JOURNAL OF ACADEMIC RESEARCH IN BUSINESS AND SOCIAL SCIENCES

Vol. 8, No. 12, Dec, 2018, E-ISSN: 2222-6990 C 2018 HRMARS

other variables, this value is still acceptable. Therefore, the data collected for this study is reliable and consistent.

Table 4.3:

Results of Reliability Test: Cronbach's Alpha

\begin{tabular}{lcc}
\hline Construct & Cronbach's Alpha & Number of Item \\
\hline Government support program & .904 & 18 \\
\hline GST compliance & .809 & 6 \\
\hline Fiscal cost & .729 & 4 \\
\hline Time cost & .927 & 4 \\
\hline Psychological cost & .828 & 4 \\
\hline
\end{tabular}

\section{Multiple Linear Regressions}

Multiple linear regression was used to determine the relationship between GSPs, compliance cost and GST compliance among the batik manufacturers. This test determines whether there is a linear relationship between the dependent and independent variables. Thus, a dummy variable was created, with the assumption that the $\mathrm{H}_{0}$ states 'There is no effect on the independent variables on the dependent variable' and $\mathrm{H}_{1}$ states 'There is an effect on the independent variables on the dependent variable'. Based on the results shown in Table 4.4, this study indicates that there is a significant linear relationship, since the $F$ test statistics ( $F=9.572)$ is in the rejection region ( $p$-values $<0.01$ ). This study concludes that there is at least one of the independent variables which are GSPs, time cost, fiscal cost and psychological cost affects the dependent variable which is the GST compliance. Thus, $\mathrm{H}_{0}$ is rejected.

Table 4.4

ANOVA Table

\begin{tabular}{lllllll}
\hline Model & $\begin{array}{l}\text { Sum } \\
\text { Squares }\end{array}$ & of & df & $\begin{array}{l}\text { Mean } \\
\text { Square }\end{array}$ & F & Sig. \\
\hline 1 & Regression & 725.375 & 4 & 181.344 & 9.572 & $.001^{\text {b }}$ \\
& Residual & 1420.825 & 75 & 18.944 & & \\
& Total & 2146.200 & 79 & & & \\
\hline
\end{tabular}

a. Dependent Variable: GST compliance

b. Predictors: (Constant), Time cost, fiscal cost, psychological costs and GSPS

In addition, Table 4.5 shows the results of the coefficient of determination. The results show that the portion of the total variation in the dependent variable is explained by the variation in the independent variable. Based on the value of $r$ square, $R^{2}$ indicates that $30.3 \%$ of the variation in GST compliance can be explained by the variation in GSPs, time cost, fiscal cost and physiological cost. 
INTERNATIONAL JOURNAL OF ACADEMIC RESEARCH IN BUSINESS AND SOCIAL SCIENCES Vol. 8, No. 12, Dec, 2018, E-ISSN: 2222-6990 @ 2018 HRMARS

Table 4.5

Coefficient of Determination

\begin{tabular}{|c|c|c|c|c|}
\hline Model & $\mathrm{R}$ & R Square & Adjusted R Square & $\begin{array}{l}\text { Std. Error of the } \\
\text { Estimate }\end{array}$ \\
\hline & $.581^{a}$ & .338 & .303 & 4.35251 \\
\hline
\end{tabular}

a. Predictors: (Constant), GST compliance, GSPS, Time cost, fiscal cost and psychological costs

Table 4.6 presents the results of the coefficient in testing the hypotheses in this study. $\mathrm{H}_{1}$, which is established to examine the effect of GSPs on GST compliance, is supported with $\beta_{1}: 0.309, t$ : 0.172 , sig: 0.044 . Such results indicate that there is a positive effect of GSPS on GST compliance among batik manufacturers in Malaysia. The results are similar with the findings in Hung et al. (2011); Ismail and Othman (2007); Saleh and Ndubisi (2006) and Yusoff et al., 2014). These studies found positive relationship between GSPs and GST compliance. The Government can increase their enforcement and provides better GSPs so that the SMEs can have better GST compliance. The result of testing $\mathrm{H}_{2}$ is not supported where $\beta_{2}: 0.543, \mathrm{t}: 0.999$, sig: 0.323 , and the fiscal cost does not affect GST compliance. According to Evans and Nam (2014); Faridy et al. (2014) and Ramli et al. (2015), the businesses often have to incur fiscal cost at the early stage of setting up the business such as buying or upgrading new accounting software and staff training expenses especially regarding on GST matters.

Table 4.6

Coefficient Result

\begin{tabular}{|c|c|c|c|c|c|c|}
\hline & \multicolumn{2}{|c|}{$\begin{array}{l}\text { Unstandardized } \\
\text { Coefficients }\end{array}$} & $\begin{array}{l}\text { Standardized } \\
\text { Coefficients }\end{array}$ & \multirow[t]{2}{*}{$\mathrm{t}$} & & \multirow[t]{2}{*}{ Sig. } \\
\hline & $\mathrm{B}$ & $\begin{array}{l}\text { Std. } \\
\text { Error }\end{array}$ & Beta & & & \\
\hline (Constant) & 8.792 & 2.771 & & & 3.17 & .002 \\
\hline & & & & & 3 & \\
\hline $\begin{array}{l}\text { Government } \\
\text { support program }\end{array}$ & .309 & .054 & .020 & .172 & & $.044^{*}$ \\
\hline Fiscal Cost & .543 & .546 & .195 & .996 & & .323 \\
\hline Time Cost & .866 & .289 & .597 & 2.996 & & $.004^{*}$ \\
\hline Psychological Cost & -.391 & .192 & -.290 & -2.038 & & $.045^{*}$ \\
\hline
\end{tabular}

* Significant at $\mathrm{p}$-value $<.05$

Variables definitions are as follows:

All the independent variables is measured as 1 (one) if the respondents' answer is strongly disagree, 2(two) if the respondents' answer is disagree, 3(three) if the respondents' answer is neutral, 4(four) if the respondents' answer is agree and 5(five) if the respondents' answer is strongly agree.

The result of the multiple regression analysis leads to the following linear model: 


$$
\begin{aligned}
Y=\beta_{0}+\beta_{1} G S P S+\beta_{2} F C & +\beta_{3} T C+\beta_{4} P C+\varepsilon \\
Y=8.792+0.309 G S P S & +0.543 F C+0.866 T C-0.391 P C \\
\text { Where } ; & =\text { GST compliance } \\
Y & =\text { constant value } \\
\beta_{0} & =\text { regression coefficient } \\
\beta_{1} & =\text { Government Support Programme } \\
\text { GSPS } & =\text { Fiscal Cost } \\
\text { FC } & =\text { Time Cost } \\
\text { TC } & =\text { Psychological Cost } \\
\text { PC } & =\text { Residual term (error) } \\
\varepsilon &
\end{aligned}
$$

The results of testing $\mathrm{H}_{3}$ are supported with the results showing $\beta 3: 0.866, \mathrm{t}: 2.996$, sig: 0.04, which indicate that time cost shows a significant positive effects towards GST compliance where the higher time cost that batik manufacturer need to incurred, will lead to higher GST compliance. Time cost seems to be an important factor that could affect GST compliance (Evans et al., 2013). Evans et al stated that SMEs could spend more time on handling GST transaction, as they will become more familiar with the term and have better understanding about GST themselves which could lead to them more compliance.

$\mathrm{H}_{4}$ are not supported with the results $\beta_{4}:-0.391$, t: -2.038 , sig: 0.045 respectively. It indicates that there are significant negative relationship between psychological costs with GST. It can be conclude that the higher physiological cost need to bear by batik manufacturer might reduce their GST compliance. The result can supported by Faridy et al. (2014) that burden of psychological cost can led company to become tax non-compliance.

\section{CONCLUSION}

The study was conducted to examine the effect of GSPs and compliance cost on GST compliance among batik manufacturers in Malaysia. The research findings revealed that GSPS has a positive relationship with GST compliance. Various initiatives under GSPs were introduced to improve GST compliance such as eVoucher to assist SMEs in acquiring new accounting software for GST submission purposes. In addition, seminars and workshops were also conducted to educate the batik manufacturers on GST compliance. The results indicate that the effort adopted by government could raise public compliance over the implementation of GST. The results are similar with the findings in Hung et al. (2011); Ismail and Othman (2007); Saleh and Ndubisi (2006) and Yusoff et al., 2014) that found positive relationship between GSPS and GST compliance.

In relation to compliance cost, the research findings showed that there are significant positive effects on time cost towards GST compliance. This indicates that the higher time cost incurred, the higher GST compliance is. However the result of the study showed that fiscal and psychological cost does not affect GST compliance. The finding implies that the higher fiscal and psychological cost will 
INTERNATIONAL JOURNAL OF ACADEMIC RESEARCH IN BUSINESS AND SOCIAL SCIENCES

Vol. 8, No. 12, Dec, 2018, E-ISSN: 2222-6990 @ 2018 HRMARS

create extra burden particularly to SMEs and will lower their GST compliance. Most of batik manufacturers need to incur high start-up cost as they do not have a proper accounting system. The results supported other findings such as Evans and Nam (2014); Faridy et al. (2014) and Ramli et al. (2015), that businesses often have to incur high fiscal cost at the early stage of setting up the business such as buying or upgrading new accounting software and staff training expenses especially regarding on GST matters.

Based on the findings, this study suggests that government agency should aware on the factors that could affect the batik manufacturers on GST compliance. This study shows that most batik manufacturers do not really understand the GST process. Continuous education on GST needs to be provided to ensure GST compliance specifically among batik manufacturer in Malaysia.

\section{REFERENCES}

Akhir, N. H. M., \& Ismail, N. W. (2015). Permasalahan Dalam Pembangunan Industri Batik Di Terengganu. In Persidangan Kebangsaan Ekonomi Malaysia (Vol. 10, pp. 239-246).

Chebusit, C., Namusonge, G. S., Biraori, O. E., \& Kipkoech, E. C. (2014). Factors Affecting Tax Compliance Among Small and Medium Enterprises in Kitale. International Journal of Recent Research in Commerce Economics and Management (IJRRCEM), 1(3), 60-75.

Eragbhe, E., \& Omoye, A. . (2014). SME Characteristics and Value Added Tax Compliance Costs In Nigeria. Mediterranean Journal of Social Sciences, 5(20), 614-620. https://doi.org/10.5901/mjss.2014.v5n20p614

Evans, C., Lignier, P., \& Tran-Nam, B. (2013). Tax Compliance Costs for the Small and Medium Enterprises: Recent Evidence from Australia. Tax Administration Research Centre Seminar, 1-35.

Evans, C., \& Nam, B. T. (2014). Tax compliance costs in New Zealand: An international comparative evaluation. The Tax Administration for the 21st Century Working Paper (Vol. 20). Retrieved from http://nzpublicfinance.com/wp-content/uploads/2014/08/20140611-Tax-AdministrationWP02_-Evans_REVISED.pdf

Faridy, N., Copp, R., Freudenberg, B., \& Sarker, T. (2014). Complexity, compliance costs and noncompliance with VAT by Small and Medium Enterprises (SMEs) in Bangladesh: Is there a relationship? Australian Tax Forum, (May 2014), 44-56.

George, D., \& Mallery, P. (2003). SPSS for Windows Step by Step: A simple guide and reference.

Glover, J., \& Tran-Nam, B. (2005). The GST recurrent compliance costs/benefits of small business in Australia: A case study approach. Journal of the Australasian Tax Teachers Association, 1(2), 237-258.

Hairuddin, H., Noor, N. L. M., \& Malik, A. M. A. (2012). Why do Microenterprise Refuse to Use Information Technology: A Case of Batik Microenterprises in Malaysia. Procedia - Social and Behavioral Sciences, 57, 494-502. https://doi.org/10.1016/j.sbspro.2012.09.1216

Hung, D. K. M., Effendi, A. A., Talib, L. S. A., \& Rani, N. A. B. A. (2011). A preliminary study of top SMES in Malaysia: Key success factor vs government support program. Journal of Global Business \& Economics, 2(1), 48-58. https://doi.org/10.1093/intimm/dxu036 
INTERNATIONAL JOURNAL OF ACADEMIC RESEARCH IN BUSINESS AND SOCIAL SCIENCES

Vol. 8, No. 12, Dec, 2018, E-ISSN: 2222-6990 @ 2018 HRMARS

Ismail, R., \& Othman, N. A. (2007). The Effectiveness of Governmet-Support Programmes Towards Business Growth. Journal of Advertising Research, 47(1), 14. https://doi.org/10.2501/S0021849907070031

Kirchler, E.,(2007). The Economic Psychology of Tax Behavior. Cambridge: Cambridge University Press Ling, S.C., Osman, A., Arman Hadi, A.B., Muhammad Safizal, A., Rana, S.M.. (2016). Public Acceptance and Compliance on Goods and Services Tax (GST) Implementation: A Case Study of Malaysia, Asian Journal of Social Sciences \& Humanities Vol. 5(1) February

Nkwe, N., (2013). Tax Payers' Attitude and Compliance Behavior among Small Medium Enterprises (SMEs) in Botswana. Business and Management Horizons, ISSN 2326-0297, 1(1).

Nunnally, J. C., \& Bernstein, I. H. (1999). Psychometric theory. McGraw-Hill. https://doi.org/10.1037/018882

Palil, M. R., Ramli, R., Mustapha, A. F., \& Hassan, N. S. A. (2013). Elements of compliance costs: Lesson from Malaysian companies towards Goods and Services Tax (GST). Asian Social Science, 9(11), 135-147. https://doi.org/10.5539/ass.v9n11p135

Rametse, N. (2010). An International Perspective on Small Business Implementation Costs of a New tax and aagerial Benefit Derived. In Transforming Black Townships into Economic Powerhouses, Proceedings of the 2010 Soweto International Conference on Entrepreneurship \& Development (pp. 1-24).

Rametse, N., \& Pope, J. (2002). Start-up Tax Compliance Costs of the GST : Empirical Evidence from Western Australian Small Businesses. Australian Tax Forum, (February).

Ramli, R., Palil, M. R., Hassan, N. S. A., \& Mustapha, A. F. (2015). Compliance Costs of Goods and Services Tax (GST) among Small and Medium Enterprises. Jurnal Pengurusan, 45.

Saad, N., (2014), Tax Knowledge, Tax Complexity and Tax Compliance: Taxpayers', Procedia - Social and Behavioral Sciences 109, $1069-1075$

Saleh, A. S., \& Ndubisi, N. O. (2006). An evaluation of SME development in Malaysia. International Review of Business ..., 2(1), 1-14. Retrieved from http://www.geasiapacifico.org/documents/IBRP1.pdf

Sandford, C. (1989). Tax Compliance Costs: Measurement and Policy. Fiscal Publications.

Tran-Nam, B. (2000). The Implementation Costs of the Gst in Australia : Concepts, Preliminary Estimates and Implications. Journal of Australian Taxatıon, (July), 331-343. https://doi.org/10.1525/sp.2007.54.1.23.

Yusoff, M. N. H., Yaacob, M. R., \& Aziz, Z. A. (2014). Why Malay Entrepreneurs Did Not Use Business Support Services in Malaysia ? Journal of Business and Social Development, 2(2), 1-8. 